\title{
DNA Fingerprinting of Crude Bacterial Lysates Using Degenerate RAPD Primers
}

\author{
Sameer A. Sakallah, Robert W. Lanning, and David L. Cooper
}

Department of Pathology, Division of Molecular Diagnostics, University of Pittsburgh Medical Center, Pittsburgh, Pennsylvania 15261

Methods for identifying isolates of various pathogenic bacteria by DNA fingerprinting with random primers (RAPD) have been described recently. In these methods many primers are screened and the primers that generate the most informative DNA pattern are selected. A new strategy that simplifies the primer selection process for RAPD fingerprinting has been developed in our laboratory. In this approach, one or more degenerate nucleotides is introduced into the core RAPD primer sequence at various nucleotide positions. Results show that a single degenerate nucleotide in the primer sequence can significantly change the DNA profile obtained for the same template. The more removed the degenerate nucleotide is from the $3^{\prime}$ end of the primer, the less dramatic is its effect on banding pattern. This method utilizing degenerate RAPD (D-RAPD) primers was tested on clinical isolates of Legionella pneumoniae, and results were confirmed with nondegenerate RAPD primers. Results obtained with D-RAPD primers were in total agreement with those obtained with nondegenerate RAPD primers. We propose that the use of a core RAPD primer sequence with one or more degenerate nucleotide(s) at various positions can expedite the generation of unique DNA fingerprints of individual organisms. A general method for selecting the most useful fingerprinting RAPD primers is discussed. $\mathbf{R}_{\text {andom amplified polymorphic DNA }}$ (RAPD) PCR fingerprinting techniques have been developed in recent years for strain identification of different bacteria such as Mycobacteria, ${ }^{(1)}$ Streptococci, ${ }^{(2)}$ Escherichia, ${ }^{(3)}$ Brucella, ${ }^{(4)}$ Pseudomonas, ${ }^{(5)}$ Helicobacter, $^{(6)}$ Enterobacter, ${ }^{(7)}$ Haemophilus $^{(8)}$ and the marine bacterium Vibrio. ${ }^{(9)}$ Random primers have also been used for identification and other applications in fungi, ${ }^{(10)}$ yeast, ${ }^{(11)}$ trypanosomes ${ }^{(12)}$ plants, ${ }^{(13)}$ fish, ${ }^{(14)}$ and humans. ${ }^{(15)}$ Typically, RAPD analysis begins by testing the ability of different primers to generate a unique and reproducible DNA-banding profile (fingerprint). This task, however, can be lengthy and expensive. In practice theoretical considerations for primer design and optimum reaction conditions often fail to produce the expected results. ${ }^{(16)}$ Thus, the screening for appropriate RAPD primers relies primarily on trial and error.

Analysis of the primer screening process reveals that by using one RAPD primer with a given sequence, the number of possible primer pairs required for successful DNA fragment amplification is 1 . By introducing a single 2-base degeneracy at any position (thus generating two primer sequences), the number of these combinations increases to 3 . Similarly, the number of primer pair combinations for a single 3-base degeneracy (three primer sequences) is 6 and for a 4-base degeneracy (four primer sequences) is 10 combinations. Although not all of these combinations are expected to be stable or productive, even one combination will be sufficient to generate one or more amplification products. Thus, rather than screening 10 individual primer pair combinations (represented in four primer sequences) for their ability to generate a unique fingerprint, only one primer with a 4-base degeneracy at one position is needed to do just that.

\section{MATERIALS AND METHODS}

Preparation of Crude Bacterial Extracts

Single colonies were picked from culture plates and suspended in $500 \mu \mathrm{l}$ of lysis buffer $(10 \mathrm{~mm}$ Tris- $\mathrm{HCl}$ at $\mathrm{pH} 8,1 \mathrm{~mm}$ EDTA, 1\% Triton X-100). Cells were lysed by heating in a heat block at $95^{\circ} \mathrm{C}$ for 30 min. After cooling to room temperature, cell lysates were stored at $-20^{\circ} \mathrm{C}$. Aliquots of this lysate were used directly in PCR.

\section{PCR}

Reactions $(25 \mu \mathrm{l})$ contained buffer (10 $\mathrm{mm}$ Tris- $\mathrm{HCl}$ at $\mathrm{pH} 8.3,50 \mathrm{mM} \mathrm{KCl}$, $0.001 \%$ gelatin), $200 \mu \mathrm{M}$ deoxynucleotide triphosphates, $4 \mathrm{~mm} \mathrm{MgCl}_{2}, 4 \mu \mathrm{M}$ primer(s), $5 \mu \mathrm{l}$ of the crude bacterial lysate, and 1 unit of Taq DNA polymerase (Perkin-Elmer). Unless stated otherwise, each lysate was analyzed at two different dilutions. For detection by autoradiography (Fig. 3, below), 1 pmole of ${ }^{32} \mathrm{P}$ endlabeled primer was added to the reaction.

Thermal cycling was carried out in a Perkin-Elmer series 9600 cycler. After an initial denaturation step at $94^{\circ} \mathrm{C}$ for 2 min, five cycles were performed as follows: $94^{\circ} \mathrm{C}$ for $30 \mathrm{sec}$, $90-\mathrm{sec}$ ramp to $30^{\circ} \mathrm{C}, 30^{\circ} \mathrm{C}$ for $30 \mathrm{sec}$ and $72^{\circ} \mathrm{C}$ for $30 \mathrm{sec}$. This was followed by 35 cycles of $94^{\circ} \mathrm{C}$ for $30 \mathrm{sec}, 90$-sec ramp to $55^{\circ} \mathrm{C}, 55^{\circ} \mathrm{C}$ for $30 \mathrm{sec}$ and $72^{\circ} \mathrm{C}$ for $30 \mathrm{sec}$. A final extension at $72^{\circ} \mathrm{C}$ was performed for $10 \mathrm{~min}$. 


\section{Gel Electrophoresis}

PCR products from reactions with different lysate dilutions were first combined, and $10-\mu \mathrm{l}$ aliquots of this mixture were mixed with $2 \mu$ l of agarose gel loading dye and electrophoresed on $4 \%$ NuSieve (3:1) agarose gels (FMC BioProducts). Electrophoresis buffer was Tris-acetate buffer ( $\mathrm{pH} 8$ ) containing $0.3 \mu \mathrm{g} / \mathrm{ml}$ of ethidium bromide. DNA bands were visualized by exposure to UV light. When end-labeled primers were used, $8 \mu$ of denaturing dye was added to each reaction, and the mixtures were denatured at $99^{\circ} \mathrm{C}$ for $15 \mathrm{~min}$ prior to electrophoresis on $8 \%$ denaturing polyacrylamide gels. DNA bands were visualized by autoradiography.

\section{Oligonucleotide Synthesis}

All PCR primers were synthesized on a Beckman Oligo 1000 instrument. Cleavage and deprotection were performed using Beckman's UltraFast kit.

\section{RESULTS}

\section{The Utility of Degenerate RAPD Primers in DNA Fingerprinting}

Fingerprint profiles of various Legionella isolates using RAPD and degenerate (D)RAPD primers were compared under identical reaction and analysis conditions. Over 50 different clinical isolates were analyzed this way (S.A. Sakallah, R.W. Lanning, D. McDevitt, D.L. Cooper, and W. Pasculle, in prep.). Representative results are shown in Figure 1. Fingerprints shown here using D-RAPD primers are similar in quality to their RAPD counterparts (not shown). Results that demonstrate different but reproducible profiles were generated by either D-RAPD or RAPD primers. Profile complexity, however, did not necessarily increase with D-RAPD primers (see below).

\section{Effect of Degenerate Nucleotides}

D-RAPD fingerprinting was carried out using a series of primers that differ in the position of the degenerate nucleotide, $\mathrm{N}$, but are otherwise identical. A single $L e-$ gionella isolate was used as the source of template DNA in all reactions. Results in Figure 2 show that placing $\mathrm{N}$ at various positions in the primer changes the DNA-banding pattern. When $\mathrm{N}$ is located in the middle of the primer, bands

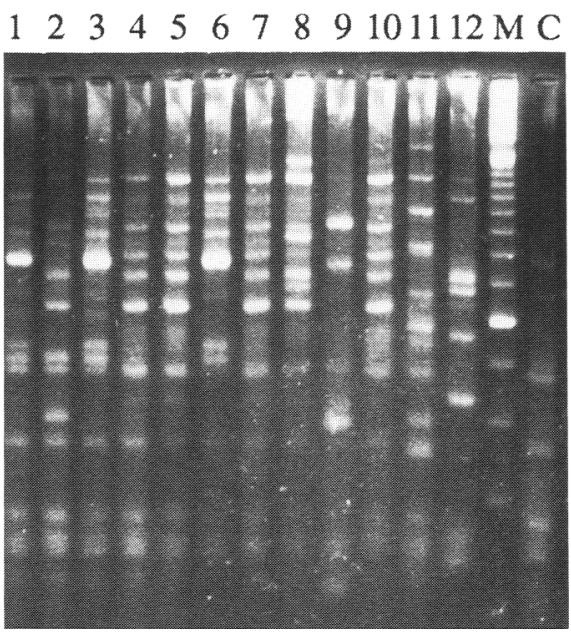

FIGURE 1 Characterization of L. pneumoniae isolates by DNA fingerprinting with RAPD and D-RAPD primers. Individual colonies from 12 patient and environmental isolates were analyzed as described in Materials and methods. Primer used was CGGCCACTGN. (Lane $M$ ) 100-bp ladder (GIBCO/BRL); (lane C) no DNA control.

that are shared with the nondegenerate primer can be detected (see below). When $\mathrm{N}$ is moved closer to the $5^{\prime}$ end of the primer, the banding pattern becomes very similar to that of that are generated by the nondegenerate primer. Moreover, increasing the degeneracy in the core primer sequence results in a different banding pattern for the same DNA template but does not necessarily increase its complexity (data not shown). This suggests that although higher primer degeneracy results in a larger theoretical number of possible primer combinations, only a subset of these may be successful in generating amplified bands. Some bands may be shared between the three profiles because some primer sequences in the less degenerate primer are present in the more degenerate one.

\section{Effect of the $\mathbf{3}^{\prime}$-end Nucleotide}

PCR reactions were carried out in duplicate using ${ }^{32} \mathrm{P}$-end-labeled primers that differ in the level of degeneracy as shown in Figure 3. As expected, our results show that changing the 3 '-terminal nucleotide in the D-RAPD primer sequence results in significant changes in the banding pattern. This was true for both degenerate and nondegenerate primers.

\section{Template Concentration}

The amount of DNA template present in PCR reactions is a major source of nonreproducibility in RAPD fingerprint analysis. ${ }^{(17)}$ It has been observed in our laboratory that some amplified bands in a given fingerprint may disappear in a selective manner as a result of decreasing template concentration in the reaction. To demonstrate this phenomenon, 10fold serial dilutions were made on the Legionella crude lysate, and D-RAPD fingerprinting was carried out on each dilution as described above. Results in Figure 4 show that the intensity of several bands, such as band B, remained essentially unchanged even at 100 -fold template dilution, whereas other bands such as band $A$ have almost disappeared at the same dilution. It is therefore important to carry out reactions with at least two dilutions and compare the profiles between the two runs to ensure consistency of banding patterns.

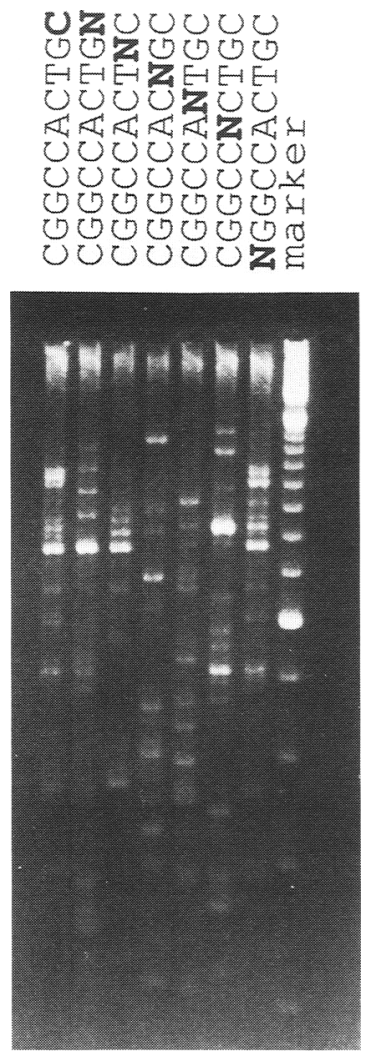

FIGURE 2 Effect of the degenerate nucleotide position on DNA-banding patterns. A set of seven primers that differ only in the position of the degenerate nucleotide, $\mathrm{N}$, was used to analyze a single $L$. pneumoniae isolate as described above. The same Legionella isolate was used in all reactions. (Marker) 100-bp ladder. 

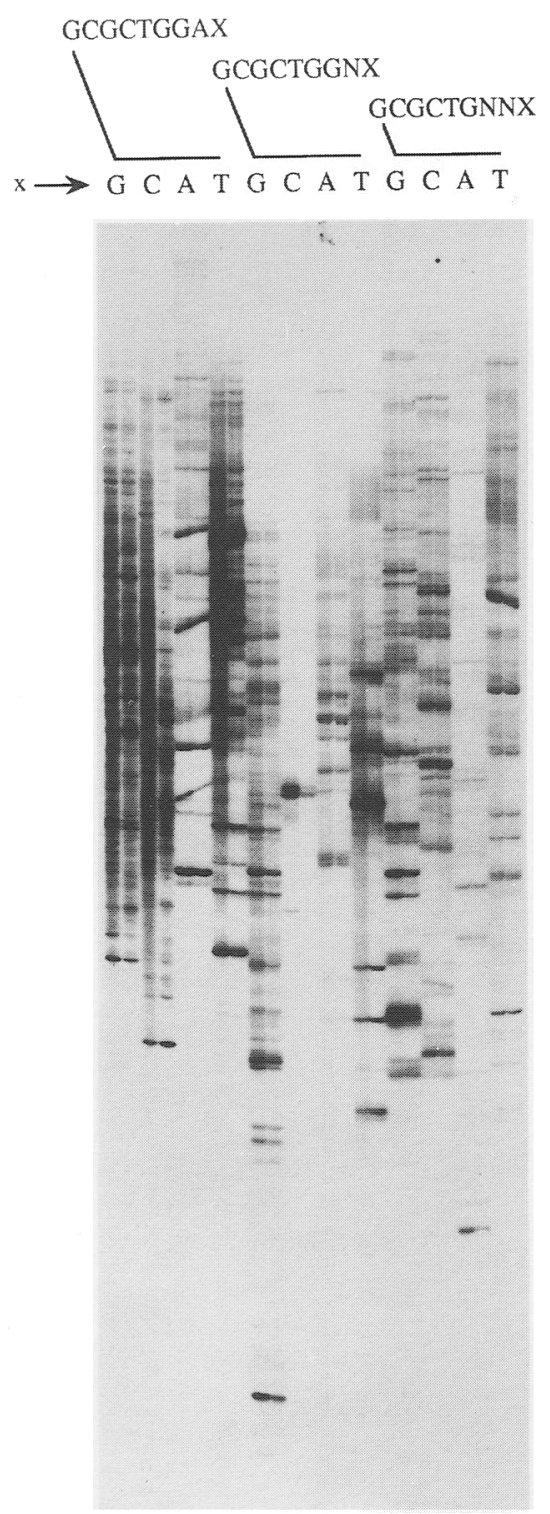

FIGURE 3 Effect of the 3 '-end nucleotide. Reactions were carried out in duplicate using a single bacterial isolate and ${ }^{32} \mathrm{P}$-end-labeled primers as described in Materials and methods. Three sets of related primers with increasing levels of degeneracy were used as outlined above. Each primer set contained four primers that differ only in the 3 '-terminal nucleotide.

\section{DISCUSSION}

D-RAPD primers were developed in this laboratory to help distinguish between clinical isolates of Legionella pneumoniae by PCR fingerprinting. These isolates were primarily environmental and patient specimens collected during a recent outbreak of Legionnaire's disease (S.A. Sakallah, R.W. Lanning, D. McDevitt,
D.L. Cooper, and W. Pasculle, in prep.). Our goal was to devise a strategy for selecting the appropriate primers for this task, as well as to simplify the RAPD primer screening process for fingerprinting of other microorganisms in the future. Our results show that DNA profiles generated by D-RAPD primers are comparable in quality and reproducibility to their nondegenerate counterparts. Occasionally, however, results may be difficult to interpret because of the presence of some faint bands or differences in the relative intensities of the bands. These effects are either real differences between different isolates, or they may be attributable to variability in the quality and quantity of the DNA in the reaction. Such ambiguities were easily resolved by analyzing banding patterns generated by several template dilutions. ${ }^{(17)}$ Variations attributable to the quality and/or the quantity of DNA usually disappear with higher dilutions, whereas genuine differences remain.

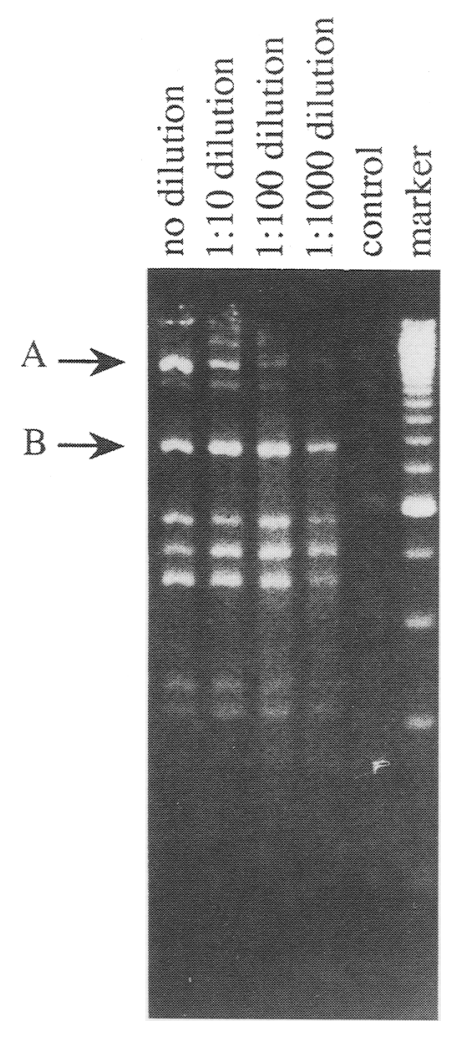

FICURE 4 Effect of template concentration. Tenfold serial dilutions of a single Legionella crude lysate were used in separate reactions. PCR reaction products from each dilution were electrophoresed individually as shown. The D-RAPD primer used here is CGGCC[C/ A]CTG[A/T] . (Control) No DNA; (marker) 100bp ladder.
To ensure the reproducibility of results, several precautions must be considered: (1) It is recommended that unique fingerprints be generated by at least two primers to confirm differences between isolates; (2) all reactions must be carried out in duplicate; and (3) PCR reactions must be performed using several serial dilutions of the crude lysate. Analysis of these reactions side by side on a gel will give an idea about the optimal template concentration range. In addition, if the reaction products from within this range are combined prior to electrophoresis, minor experimental inconsistencies will be diluted out. Finally, although autoclaved, filtered, doubledistilled water may be used as control, strong bands may still be detected in control reactions. These bands are derived either from small DNA fragments that could not be removed by filtration or the Taq DNA polymerase itself, which may not be $100 \%$ DNA-free. ${ }^{(18)}$ These bands, however, do not cause serious problems in interpreting the results, as they can be easily subtracted from the experimental lanes. The problem may be minimized by decontaminating all reagents, except enzyme and template, and by UV irradiation at $254 \mathrm{~nm}$ for 5 min prior to their use.

Results presented here demonstrate that introduction of degenerate nucleotides in the primer sequence can significantly simplify the process of screening large numbers of random primers. However, the specific primer pair combinations that generated the unique DNA profile will not be readily known. It has been reported that nucleotides at or close to the $3^{\prime}$ end are very important in determining the enzyme binding and primer extension. ${ }^{(18)}$ Thus, it is possible to identify these specific primer sequences by setting up a set of four reactions using primers of the general sequence $x x x \quad x x x x N N n$, where $x$ is any nucleotide, $N$ is a degenerate nucleotide, and $n$ is the 3 '-terminal nucleotide of the four primers. The reaction that generates the most informative banding pattern can then be identified (e.g., with a $G$ at the $3^{\prime}$ end), and a new set of four primers with the general sequence $x x x \times x x \times N n$ G are synthesized and used in the next set of reactions. This process is repeated until all three terminal nucleotides that generate the best DNA profile are identified. This strategy will reduce the number of primers needed to generate the 
best fingerprint from 64 primers to only 12.

\section{ACKNOWLEDGMENTS}

We thank Dr. William Pasculle and Mr. David McDevitt for providing the Legionella isolates and valuable discussions. Partial funding was provided by the Pathology Education and Research Foundation (PERF).

\section{REFERENCES}

1. Linton, C.J., H. Jalal, J.P. Leeming, and M.R. Millar. 1994. Rapid discrimination of Mycobacterium tuberculosis strains by random amplified polymorphic DNA analysis. J. Clin. Microbiol. 32: 2169-2174.

2. Jayarao, B.M., B.J. Bassam, G. CaetanoAnolles, P.M. Gresshoff, and S.P. Oliver. 1992. Subtyping of Streptococcus uberis by DNA amplification fingerprinting. $J$. Clin. Microbiol. 30: 1347-1350.

3. Brikun, I., K. Suziedelis, and D.E. Berg. 1994. DNA sequence divergence among derivatives of Escherichia coli $\mathrm{K}-12$ detected by arbitrary primer PCR (random amplified polymorphic DNA) fingerprinting. J. Bacteriol. 176: 1673-1682.

4. Fekete, A., J.A. Bantle, S.M. Halling, and W. Stich. 1992. Amplification fragment length polymorphism in Brucella strains by use of polymerase chain reaction with arbitrary primers. J. Bacteriol. 174: 77787783.

5. Elaichouni, A., G. Verschraegen, G. Claeys, M. Devleeschouwer, C. Godard, and M. Vaneechoutte. 1994. Pseudomonas aeruginosa serotype $\mathrm{O} 12$ outbreak studied by arbitrary primer PCR. J. Clin. Microbiol. 32: 666-671.

6. Akopyanz, N., N.O. Bukanov, T.U. Westblom, S. Kresovich, and D.E. Berg. 1992. DNA diversity among clinical isolates of Helicobacter pylori detected by PCRbased RAPD fingerprinting. Nucleic Acids Res. 20: $5137-5142$.

7. Grattard, F., B. Pozzetto, P. Berthelot, I. Rayet, A. Ros, B. Lauras, and O. Gaudin. 1994. Arbitrarily primed PCR, ribotyping, and plasmid pattern analysis applied to investigation of a nosocomial outbreak due to Enterobacter cloacae in a neonatal intensive care unit. J. Clin. Microbiol. 32: 596-602.

8. Myers, L.E., S.V. Silva, J.D. Procunier, and P.B. Little. 1993. Genomic fingerprinting of "Haemophilus somnus" isolates by using a random-amplified polymorphic DNA assay. J. Clin. Microbiol. 31: 512-517.

9. Martin-Kearley, J., J.A. Gow, M. Pquin, and C.W. Greer. 1994. Numerical analysis and the application of random amplified polymorphic DNA polymerase chain reac- tion to the differentiation of Vibrio strains from a seasonally cold ocean. Can. J. Microbiol. 40: 446-455.

10. Fujimori, F. and T. Okuda. 1994. Application of the random amplified polymorphic DNA using the polymerase chain reaction for efficient elimination of duplicate strains in microbial screening. I. Fungi. J. Antibiot. (Tokyo). 47: 173-182.

11. Anzai, Y., T. Okuda, and J. Watanabe. 1994. Application of the random amplified polymorphic DNA using the polymerase chain reaction for efficient elimination of duplicate strains in microbial screening. II. Actinomycetes. /. Antibiot. (Tokyo). 47: 183-193.

12. Murphy, N.B. and R. Pell. 1994. The use of arbitrary primers and the RADES method for the rapid identification of developmentally regulated genes in trypanosomes. Gene 141: 53-61.

13. Grattapaglia, D. and R. Sederoff. 1994. Genetic linkage maps of Eucalyptus grandis and Eucalyptus urophylla using a pseudotestcross: Mapping strategy and RAPD markers. Genetics 137: 1121-1137.

14. Johnson, S.L., C.N. Midson, E.W. Ballinger, and J.H. Postlethwait. 1994. Identification of RAPD primers that reveal extensive polymorphisms between laboratory strains of Zebrafish. Genomics 19: 152-156.

15. Williams, J.G.K., A.R. Kubelik, K.J. Livak, J.A. Rafalski, and S.V. Tingey. 1990. DNA polymorphisms amplified by arbitrary primers are useful as genetic markers. $\mathrm{Nu}$ cleic Acids Res. 18: 6531-6535.

16. Caetano-Anolles, G. 1994. MAAP: A versatile and universal tool for genome analysis. Plant Mol. Biol. 25: 1011-1026.

17. McClelland, M. and J. Welsh. 1994. DNA fingerprinting by arbitrarily primer PCR. PCR Methods Applic. 4: S59-S65.

18. Maiwald, M., H.-J. Ditton, H.-G. Sonntag, and M.V.K. Doeberitz. 1994. Characterization of contaminating DNA in Taq polymerase which occurs during amplification with a primer set for legionella $5 \mathrm{~S}$ ribosomal RNA. Mol. Cell. Probes 8: 11-14.

Received January 9, 1995; accepted in revised form February 15, 1995. 


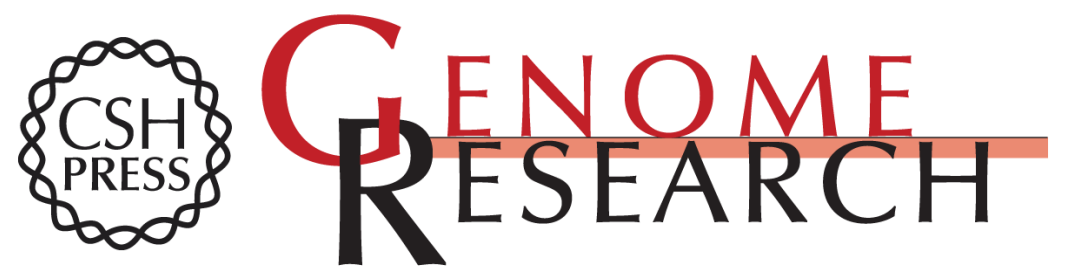

\section{DNA fingerprinting of crude bacterial lysates using degenerate RAPD primers.}

S A Sakallah, R W Lanning and D L Cooper

Genome Res. 1995 4: 265-268

References This article cites 18 articles, 8 of which can be accessed free at: http://genome.cshlp.org/content/4/5/265.full.html\#ref-list-1

\section{License}

Email Alerting

Receive free email alerts when new articles cite this article - sign up in the box at the Service top right corner of the article or click here.

\section{Affordable, Accurate Sequencing.}

To subscribe to Genome Research go to: https://genome.cshlp.org/subscriptions 